\title{
Two Pathway-Specific Transcriptional Regulators, PltR and PltZ, Coordinate Autoinduction of Pyoluteorin in Pseudomonas protegens Pf-5
}

\author{
Qing Yan ${ }^{1,2, *,+} \mathbb{D}$, Mary Liu ${ }^{2}$, Teresa Kidarsa ${ }^{3}$, Colin P. Johnson ${ }^{4}$ and Joyce E. Loper ${ }^{1,3}$ \\ 1 Department of Botany and Plant Pathology, Oregon State University, Corvallis, OR 97331, USA; \\ Joyce.Loper@oregonstate.edu \\ 2 Department of Plant Sciences and Plant Pathology, Montana State University, Bozeman, MT 59717, USA; \\ mliu@montana.edu \\ 3 Horticultural Crops Research Laboratory, US Department of Agriculture, Agricultural Research Service, \\ Corvallis, OR 97330, USA; tkidarsa@gmail.com \\ 4 Department of Biochemistry and Biophysics, Oregon State University, Corvallis, OR 97331, USA; \\ Colin.Johnson@oregonstate.edu \\ * Correspondence: qing.yan@montana.edu \\ + Present address: Department of Plant Sciences and Plant Pathology, Montana State University, \\ Bozeman, MT 59717, USA.
}

check for updates

Citation: Yan, Q.; Liu, M.; Kidarsa, T.; Johnson, C.P.; Loper, J.E. Two Pathway-Specific Transcriptional Regulators, PltR and PltZ, Coordinate Autoinduction of Pyoluteorin in Pseudomonas protegens Pf-5. Microorganisms 2021, 9, 1489. https://doi.org/10.3390/ microorganisms 9071489

Academic Editors: Jacob G. Malone and Rafael Rivilla

Received: 15 June 2021

Accepted: 10 July 2021

Published: 13 July 2021

Publisher's Note: MDPI stays neutral with regard to jurisdictional claims in published maps and institutional affiliations.

Copyright: (c) 2021 by the authors. Licensee MDPI, Basel, Switzerland. This article is an open access article distributed under the terms and conditions of the Creative Commons Attribution (CC BY) license (https:// creativecommons.org/licenses/by/ $4.0 /)$.

\begin{abstract}
Antibiotic biosynthesis by microorganisms is commonly regulated through autoinduction, which allows producers to quickly amplify the production of antibiotics in response to environmental cues. Antibiotic autoinduction generally involves one pathway-specific transcriptional regulator that perceives an antibiotic as a signal and then directly stimulates transcription of the antibiotic biosynthesis genes. Pyoluteorin is an autoregulated antibiotic produced by some Pseudomonas spp. including the soil bacterium Pseudomonas protegens Pf-5. In this study, we show that PltR, a known pathway-specific transcriptional activator of pyoluteorin biosynthesis genes, is necessary but not sufficient for pyoluteorin autoinduction in Pf-5. We found that pyoluteorin is perceived as an inducer by PltZ, a second pathway-specific transcriptional regulator that directly represses the expression of genes encoding a transporter in the pyoluteorin gene cluster. Mutation of plt $Z$ abolished the autoinducing effect of pyoluteorin on the transcription of pyoluteorin biosynthesis genes. Overall, our results support an alternative mechanism of antibiotic autoinduction by which the two pathwayspecific transcriptional regulators PltR and PltZ coordinate the autoinduction of pyoluteorin in Pf-5. Possible mechanisms by which PltR and PltZ mediate the autoinduction of pyoluteorin are discussed.
\end{abstract}

Keywords: autoinduction; pyoluteorin; transporter; regulation; Pseudomonas protegens

\section{Introduction}

Autoinduction, also called positive feedback regulation, is commonly used by bacteria to induce phenotypes required to respond promptly to a particular environmental condition [1-3]. The best-documented mechanism is the autoinduction of N-acyl-homoserine lactones, also known as quorum sensing signal molecules, which regulate cell-to-cell communication in many bacteria. In a classic model, $N$-acyl-homoserine lactone binds to its cognate response regulator and directly activates expression of $\mathrm{N}$-acyl-homoserine lactone biosynthesis gene(s), which leads to an enhanced level of the signal molecule [4].

In addition to the quorum sensing signal molecules, production of many antibiotics is also controlled by autoinduction [5-15]. Through autoregulation, antibiotics can accumulate rapidly, allowing producers to respond promptly to competition with other microorganisms or predators [7]. Some antibiotics, such as 2,4-diacetylphloroglucinol [16] and jadomycins [14], bind to their cognate response regulators and directly induce expression of antibiotic biosynthesis genes, a mechanism similar to the autoinduction of quorum 
sensing signal molecules. For the vast majority of antibiotics, however, mechanisms of autoinduction are unknown.

This study focuses on the autoinduction of pyoluteorin, a broad-spectrum antibiotic produced by certain strains of Pseudomonas species including P. aeruginosa [17] and P. protegens (previously known as P. fluorescens) [18]. Autoinduction of pyoluteorin was first demonstrated in P. protegens Pf-5. Adding nanomolar concentrations of pyoluteorin to Pf$5^{\prime}$ s cultures enhanced pyoluteorin production and transcription of pyoluteorin biosynthesis genes [9]. Later, pyoluteorin autoinduction was also observed in P. protegens CHA0 [19] and $P$. aeruginosa M18 [20]. Production of pyoluteorin requires a pathway-specific response regulator PltR (Figure 1) [21], which binds to the promoter region of pyoluteorin biosynthesis genes and activates their transcription [22]. PltR belongs to the LysR family regulators, which generally require activators for their activities [23]. Pyoluteorin was proposed to bind directly to PltR, thereby promoting PltR-mediated transcriptional activation of pyoluteorin biosynthesis genes and mediating autoinduction [22]. However, 2,4-dichlorobenzene-1,3,5-triol, a chlorinated phloroglucinol $\left(\mathrm{PG}^{-} \mathrm{Cl}_{2}\right)$ with a chemical structure distinct from pyoluteorin (Figure 1A), is now known to be required for PltR-mediated activation of pyoluteorin production and its biosynthesis genes [24]. Mechanisms of pyoluteorin autoinduction remain unknown. Here we report that PltR is required but not sufficient for pyoluteorin autoinduction, and that PltZ, a second transcriptional regulator encoded in the plt gene cluster (Figure 1A), binds directly to pyoluteorin as an inducer and is also required for pyoluteorin autoinduction.

(A)<smiles>O=C(c1cc(Cl)c(Cl)[nH]1)c1c(O)cccc1O</smiles>

Pyoluteorin<smiles>Oc1cc(O)c(O)c(O)c1O</smiles>

$\mathrm{PG}-\mathrm{Cl}_{2}$

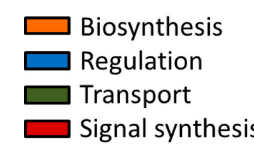

Transport

(B)

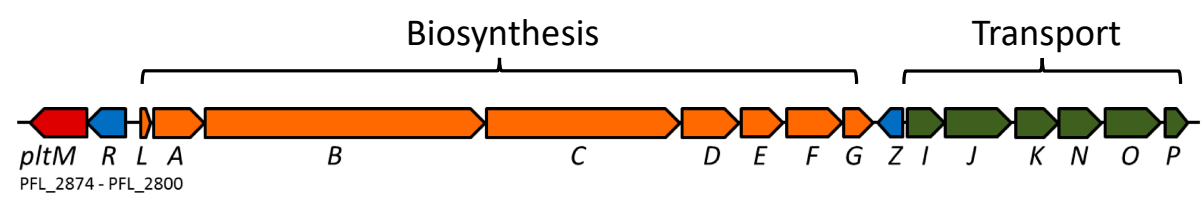

(C)

$$
\begin{aligned}
& \varliminf_{p l t R} \prod_{L:: g f p} p L-g f p \\
& \bigotimes_{p l t R} \prod_{L:: g f p} p R L-g f p
\end{aligned}
$$

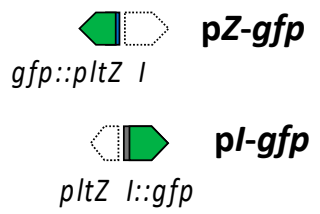

Figure 1. Chemical structures of pyoluteorin and PG-Cl 2 (2,4-dichlorobenzene-1,3,5-triol) (A), pyoluteorin biosynthesis gene ( $p l t)$ cluster of Pf-5 (B), and promoter:: $g f p$ fusions of the transcriptional reporter constructs used in this work $(\mathbf{C})$. Figures are modified from previous publication [24]. The plt gene cluster contains two transcriptional regulatory genes $p l t R$ and $p l t Z$. $P G-\mathrm{Cl}_{2}$, an activator of PltR, is synthesized by PltM with phloroglucinol (PG) as a substrate. Open arrows in (C) indicate the genes are not included in the related constructs.

\section{Materials and Methods}

\subsection{Strains and Cultural Conditions}

The bacterial strains used in this study are listed in Table 1. Pseudomonas protegens Pf-5 and its mutants were cultured at $27^{\circ} \mathrm{C}$ on King's Medium B agar [25], Nutrient Agar (Becton, Dickinson and Company, Sparks, MD) supplemented with 1\% glycerol (NAGly) or Nutrient Broth (Becton, Dickenson, and Company) supplemented with $1 \%$ glycerol (NBGly). Liquid cultures were grown with shaking at 200 r.p.m. 
Table 1. Bacterial strains, plasmid, and primers used in this study.

\begin{tabular}{|c|c|c|}
\hline Strains, Plasmids, or Primers & $\begin{array}{c}\text { Genotype, Relevant } \\
\text { Characteristics or Sequences }\end{array}$ & Reference or Source \\
\hline \multicolumn{3}{|l|}{ Strains \# } \\
\hline \multicolumn{3}{|l|}{ P. protegens } \\
\hline LK099 & Wild-type strain Pf-5. & [26] \\
\hline JL4805 & $\begin{array}{l}\text { Pf- } 5 \text { derivative strain contains } \\
\text { an in-frame deletion of plt } A \text { in } \\
\text { the chromosome. }\end{array}$ & [27] \\
\hline LK530 & $\begin{array}{l}\text { Pf- } 5 \text { derivative strain contains } \\
\text { an in-frame deletion of } p l t A \\
\text { and } p l t R \text { in the chromosome. } \\
\text { This mutant was generated by } \\
\text { deleting pltR in JL4805. }\end{array}$ & This study \\
\hline LK419 & $\begin{array}{l}\text { Pf- } 5 \text { derivative strain contains } \\
\text { an in-frame deletion of } p l t A \\
\text { and pltZ in the chromosome. } \\
\text { This mutant was generated by } \\
\text { deleting pltZ in JL4805. }\end{array}$ & This study \\
\hline P. fluorescens SBW25 & $\begin{array}{l}\text { SBW25 is a member of the } P \text {. } \\
\text { fluorescens group that does not } \\
\text { contain plt gene cluster. }\end{array}$ & [28] \\
\hline \multicolumn{3}{|l|}{ E. coli } \\
\hline S17-1 & $\begin{array}{c}\text { recA pro hsdR }{ }^{-} \mathrm{M}^{+} \mathrm{RP} 4 \\
\text { 2-Tc::Mu-Km::Tn7 Sm}{ }^{\mathrm{r}} \mathrm{Tp}^{\mathrm{r}}\end{array}$ & [29] \\
\hline BL21 (DE3) & $\operatorname{ompT} h s d \mathrm{~S}_{\mathrm{B}}\left(\mathrm{r}_{\mathrm{B}}{ }^{-} \mathrm{m}_{\mathrm{B}}{ }^{-}\right) g a l d c m$ & NEB \\
\hline \multicolumn{3}{|l|}{ Plasmids } \\
\hline $\mathrm{pEX} 18 \mathrm{Tc}$ & $\begin{array}{l}\text { Gene replacement vector with } \\
\text { MCS from pUC18, sacB }{ }^{+} \mathrm{Tc}^{\mathrm{r}}\end{array}$ & {$[30]$} \\
\hline $\mathrm{pEX} 18 \mathrm{Tc}-\Delta p l t R$ & $\begin{array}{l}\text { pEX18Tc containing pltR with } \\
\text { a 925-bp in-frame deletion. }\end{array}$ & {$[24]$} \\
\hline pEX18Tc- $\Delta p l t Z$ & $\begin{array}{l}\text { pEX18Tc containing } p l t Z \text { with } \\
\text { a 621-bp in-frame deletion. }\end{array}$ & This study \\
\hline pPROBE-NT & $\begin{array}{l}\text { pBBR1, containing a } \\
\text { promoterless } g f p, \mathrm{Km}^{\mathrm{r}}\end{array}$ & [31] \\
\hline $\mathrm{p} L-g f p$ & $\begin{array}{l}\text { Called ppltL-gfp previously. } \\
\text { Contains the intergenic region } \\
\text { between } p l t R \text { and } p l t L \\
\text { including } p l t L \text { promoter fused } \\
\text { with a promoterless } g f p .\end{array}$ & [32] \\
\hline $\mathrm{p} R L-g f p$ & $\begin{array}{l}\text { Contains } p l t R \text { and the } \\
\text { intergenic region between } p l t R \\
\text { and } p l t L \text { including } p l t L \\
\text { promoter fused with a } \\
\text { promoterless } g f p \text {. }\end{array}$ & [24] \\
\hline $\mathrm{p} I-g f p$ & $\begin{array}{l}\text { Contains the intergenic region } \\
\text { between pltI and pltZ } \\
\text { including pltI promoter fused } \\
\text { with a promoterless } g f p .\end{array}$ & This study \\
\hline $\mathrm{pZ}-g f p$ & $\begin{array}{l}\text { Contains the intergenic region } \\
\text { between } p l t I \text { and } p l t Z \\
\text { including } p l t Z \text { promoter fused } \\
\text { with a promoterless } g f p .\end{array}$ & This study \\
\hline
\end{tabular}


Table 1. Cont.

\begin{tabular}{|c|c|c|}
\hline Strains, Plasmids, or Primers & $\begin{array}{c}\text { Genotype, Relevant } \\
\text { Characteristics or Sequences }\end{array}$ & Reference or Source \\
\hline pME6010 & $\begin{array}{c}\text { pACYC177-pVS1 shuttle } \\
\text { vector, } \mathrm{Tc}^{\mathrm{r}}\end{array}$ & [33] \\
\hline PME6010-pltZ & $\begin{array}{l}\text { pME6010 with a 697-bp } \\
\text { XhoI-KpnI PCR fragment } \\
\text { amplified from the genomic } \\
\text { DNA of Pf-5, containing a } \\
\text { constitutively expressed pltZ } \\
\text { gene. }\end{array}$ & This study \\
\hline Primers * & $\begin{array}{l}\text { oligonucleotide sequences } \\
\left(5^{\prime} \text { to } 3^{\prime}\right)\end{array}$ & \\
\hline pltZ-F2 & \multicolumn{2}{|c|}{ ACTCGAGAAAATAACAGATACTGGCCATG } \\
\hline pltZ-R2 & \multicolumn{2}{|c|}{ ATAGGTACCGACTATTGGGCAATGGC } \\
\hline pltI-F1 & \multicolumn{2}{|c|}{ ATAGGATCCAGCAGACGGAATTTGGGC } \\
\hline pltI-R1 & \multicolumn{2}{|c|}{ TATGGTACCCCTACAATCAACTGCTTCTTC } \\
\hline pltI-F4 & \multicolumn{2}{|l|}{ TGGCGAATGTCGACGTTGC } \\
\hline pltI-R4 & \multicolumn{2}{|c|}{ TATGAATTCCTCGTGGTCTGAGCGG } \\
\hline pltZ 5'primer & \multicolumn{2}{|c|}{ GTCATACATATGAAGCAACCCCCCGCTC } \\
\hline pltZ 3'primer & \multicolumn{2}{|c|}{ ATGATCTCGAGCCGACTATTGGGCAATG } \\
\hline pltZ UpF-Xba & \multicolumn{2}{|c|}{ СТССТCTCTAGATCAAAACGTGCCTTGGACTG } \\
\hline pltZ UpR & \multicolumn{2}{|c|}{ ACTATTGGGCAATGATGTTCCTCGTGGTCTGAG } \\
\hline pltZ DnF & \multicolumn{2}{|c|}{ ACGAGGAACATCATTGCCCAATAGTCGGCTCA } \\
\hline pltZ DnR-Xba & \multicolumn{2}{|c|}{ CACACCTCTAGAACATCCCСTGCTGTTTCTTC } \\
\hline
\end{tabular}

\# abbreviations of antibiotics and their concentrations used in this work are: Tc, tetracycline $(10 \mu \mathrm{g} / \mathrm{mL}$ for E. coli, $200 \mu \mathrm{g} / \mathrm{mL}$ for Pf-5); Km, kanamycin $(50 \mu \mathrm{g} / \mathrm{mL}) .{ }^{*}$ underlines show DNA restriction enzyme sites that were used for cloning. All primers were designed in this study.

\subsection{Construction of GFP Transcriptional Reporters and Expression Constructs}

To measure the promoter activity of pltZ, a 235-bp DNA fragment containing pltZ promoter was amplified from the Pf-5 genome using oligonucleotide pair pltI-F4/pltI-R4 (Table 1), digested with EcoRI and SalI, and ligated into pPROBE-NT to generate reporter construct $\mathrm{pZ}-g f p$ which contains the $p l t Z_{\text {promoter }}: g f p$ transcriptional fusion. Similarly, a 574-bp DNA fragment containing pltI promoter was amplified using oligonucleotide pair pltI-F1/pltI-R1 (Table 1), digested with BamHI and KpnI, and ligated into pPROBE-NT to generate reporter construct $\mathrm{pI}-g f p$ which contains the $p l t I_{\text {promoter }}$ : $f p$ transcriptional fusion.

The expression construct pME6010-pltZ was made by inserting a 697-bp XhoI-KpnI PCR fragment containing the entire $p l t Z$ gene and a 21-bp $5^{\prime}$ untranslated region of $p l t Z$, into pME6010 digested by the same restriction enzymes. This DNA fragment was amplified from the genomic DNA of Pf-5 using oligonucleotide pair pltZ-F2/pltZ-R2 (Table 1). The expression of $\mathrm{pltZ}$ gene was placed under the control of a constitutive kanamycin-resistance promoter (Pk) carried by the vector pME6010 [33].

The expression construct pET28a-pltZ was made by inserting a 692-bp XhoI-NdeI PCR fragment containing pltZ gene into $\mathrm{pET} 28 \mathrm{a}$ digested by the same restriction enzymes. This DNA fragment was amplified from the genomic DNA of Pf-5 using oligonucleotide pair pltZ 5' / pltZ $3^{\prime}$ (Table 1). Purified PltZ protein from the generated expression construct contains a $6 \mathrm{xHis}$ tag at the $\mathrm{N}$-terminus. All these constructs were confirmed by Sanger sequencing analysis. 


\subsection{Construction of Pf-5 Mutants}

The $\Delta$ pltA $\Delta$ pltR double mutant was made by deleting $p l t R$ from the chromosome of a $\triangle$ pltA mutant which was made previously [27]. To delete plt $R$ gene from the chromosome of Pf-5, a pltR deletion construct P18Tc- $\Delta$ pltR, which was made previously [24], was transferred by conjugation from E. coli S17-1 to Pf-5 to delete 925-bp inside of the pltR gene in the chromosome of Pf-5. The deletion was confirmed by PCR analysis.

Similarly, the $\triangle p l t A \triangle p l t Z$ double mutant was made by deleting pltZ from the chromosome of the $\triangle$ pltA mutant. To delete the pltZ, two DNA fragments flanking the pltZ gene were PCR amplified using the oligonucleotide pair pltZ UpF-Xba/pltZ UpR and pltZ DnR$\mathrm{Xba} / \mathrm{pltZ}$ DnF (Table 1). These two fragments were fused together by PCR and digested using $\mathrm{XbaI}$ to generate a 1003-bp DNA fragment containing pltZ with a 621-bp internal deletion. This DNA fragment was ligated to $\mathrm{pEX} 18 \mathrm{Tc}$ to create construct $\mathrm{p} 18 \mathrm{Tc}-\Delta \mathrm{pltZ}$. This deletion construct was introduced into the $\Delta$ pltA mutant to make the $\Delta$ plt $A \Delta p l t Z$ double mutant.

\subsection{Assays for Monitoring GFP Activity of Reporter Constructs}

The GFP-based transcriptional reporter assays were modified from a previous report [32]. Briefly, Pf-5 strains containing reporter constructs were cultured overnight in NBGly plus kanamycin $(50 \mu \mathrm{g} / \mathrm{mL})$ at $27^{\circ} \mathrm{C}$ with shaking at 200 r.p.m. The cells were washed once into $1 \mathrm{~mL}$ fresh NBGly plus kanamycin with an optical density at $600 \mathrm{~nm}$ $\left(\mathrm{OD}_{600}\right)$ of 1.0 , and then used to inoculate $200 \mu \mathrm{L}$ NBGly plus kanamycin to obtain a start $\mathrm{OD}_{600}$ of 0.01 . Each strain was grown in three wells of a 96-well plate, which was incubated in a microplate shaker at $27^{\circ} \mathrm{C}$ with shaking at approximately 400 r.p.m. Bacterial growth was monitored by measuring the $\mathrm{OD}_{600}$. The green fluorescence of bacteria was monitored by measuring emission at $535 \mathrm{~nm}$ with an excitation at $485 \mathrm{~nm}$ and corrected for background by subtracting fluorescence emitted by control strain which has an empty vector of the reporter construct.

\subsection{Protein Purification and In Vitro Activity Assays}

Protein overexpression and purification of PltZ was modified from previous method [24]. Briefly, the construct pET28a-pltZ was transformed into E. coli BL21 (DE3). Cells were cultured in LB broth with $50 \mu \mathrm{g} / \mathrm{mL}$ kanamycin at $37^{\circ} \mathrm{C}$ to an $\mathrm{OD}_{600}$ of 0.5 , then induced by $0.4 \mathrm{mM}$ IPTG, and incubated overnight at $20^{\circ} \mathrm{C}$. The cells were lysed in Tris-NaCl buffer $(20 \mathrm{mM}$ Tris $\mathrm{pH}$ 7.0, $100 \mathrm{mM} \mathrm{NaCl}$ ). The PltZ proteins with a N-terminal 6xHis tag were purified using a Ni-NTA Purification System (Invitrogen) and dialyzed in Tris-NaCl buffer. The protein concentrations were determined using a DC Protein Assay (Bio-Rad, Hercules, CA, USA).

Electrophoretic Mobility Shift Assay (EMSA) experiments were performed at $25^{\circ} \mathrm{C}$ using a LightShift ${ }^{\mathrm{TM}}$ Chemiluminescent EMSA Kit (ThermoFisher). A 44-bp DNA probe named pltIZ (TATTTTCTAATTTAAATTCAAATTGAATTTTAATTAGGCCTTGG) and a 66-bp DNA probe named $p l t R L$ (TCGGGGCTGTTTTGCCTTTGCGGATATGCAAAGGCCTTTTGCAAAAACGGCTATTCACAAGTGCAT), that contain the putative promoter region of pltI and pltL, respectively, were synthesized and labeled with biotins using a Biotin $3^{\prime}$ End DNA Labeling Kit (ThermoFisher). Labeled DNA probes $(1 \mathrm{nM})$ were mixed with different concentrations of PltZ protein and incubated at $25^{\circ} \mathrm{C}$ for $20 \mathrm{~min}$ in a $20 \mu \mathrm{L}$ reaction. If needed, unlabeled DNA probes $(1 \mu \mathrm{M})$ were used to compete with the labeled DNA in binding PltZ. Various concentrations of pyoluteorin were added in the reaction to test if this compound can release free DNA probes from the protein-DNA complex. The reaction samples were loaded to a 5\% native PAGE gel (Mini-PROTEAN ${ }^{\circledR}$ TBE Gel, Bio-Rad) and electrophorized in $0.5 \times$ Tris Borate-EDTA (TBE) buffer at $80 \mathrm{~V}$ for one hour in a $4{ }^{\circ} \mathrm{C}$ cold room. The DNA samples were transferred onto a nylon membrane (ZetaProbe ${ }^{\circledR}$ Membrane, $9 \times 12 \mathrm{~cm}$, Bio-Rad) which then was exposed to a UV light treatment at $254 \mathrm{~nm}$ for $10 \mathrm{~min}$ to fix the nucleotides and the images were developed using $X$-ray films (CL-XPosure ${ }^{\mathrm{TM}}$ Film, ThermoFisher). 
Interaction of PltZ with pyoluteorin was tested by two approaches. In the first approach, different concentrations $(0-57.5 \mu \mathrm{M})$ of pyoluteorin were added into a PltZ protein solution $(39 \mu \mathrm{M})$ which was prepared in a Tris- $\mathrm{HCl}$ buffer $(20 \mathrm{mM}$ Tris-HCL, $\mathrm{pH}$ 7.0). Absorbance of PltZ protein, pyoluteorin compound and their complex was measured in a 1-cm-path cuvette using a UV-vis spectrophotometer (Beckman DU730). The proteincompound solution which contains PltZ protein over saturated with pyoluteorin compound $(57.5 \mu \mathrm{M})$ was loaded onto a Sephadex G-25 column $(1 \times 20 \mathrm{~cm})$ preequilibrated and washed with $80 \mathrm{~mL}$ of the Tris-HCl buffer. The PltZ-pyoluteorin complex was eluted with $7 \mathrm{~mL}$ of the Tris- $\mathrm{HCl}$ buffer. The absorbance of purified PltZ-pyoluteorin complex was measured using the same method described above.

In the second approach, Isothermal titration calorimetry (ITC) experiments were performed at $25^{\circ} \mathrm{C}$ using a MicroCal VP-ITC microcalorimeter (Malvern, US). Pyoluteorin was dissolved in methanol first and then diluted in the Tris- $\mathrm{HCl}$ buffer to a concentration of $100 \mu \mathrm{M}$. The titration assay included an initial $2 \mu \mathrm{L}$ injection, followed by $44(10 \mu \mathrm{L})$ injections of pyoluteorin into PltZ protein solution prepared above, accompanied by stirring at a constant rate. Protein samples and compound solutions were degassed by centrifugation at 14,000 r.p.m. for $20 \mathrm{~min}$ prior to the titration experiment. Data were processed using Origin 7.0 and fit to an independent binding model to calculate the thermodynamic parameters of interactions between PltZ and pyoluteorin.

\section{Results}

\subsection{PltR Is Required But Not Sufficient for the Autoinduction of Pyoluteorin}

To investigate the autoinduction of pyoluteorin, purified pyoluteorin was added into cultures of Pf-5 strains. A $\triangle$ pltA mutant was used to exclude the influence of internal pyoluteorin on the expression of pyoluteorin biosynthesis genes. The promoter activity of $p l t L$, the first gene of the pyoluteorin biosynthesis gene cluster, was measured using the reporter construct $\mathrm{pL}-g f p$ which contains the $p l t L$ promoter fused with a promterless gfp (Figure 1B) [32]. Results show that amendment of pyoluteorin induced a significantly higher promoter activity of $p l t L$ in both the wild type Pf- 5 and the $\Delta p l t A$ mutant than in control cultures without pyoluteorin treatment (Figure 2A).

(A)

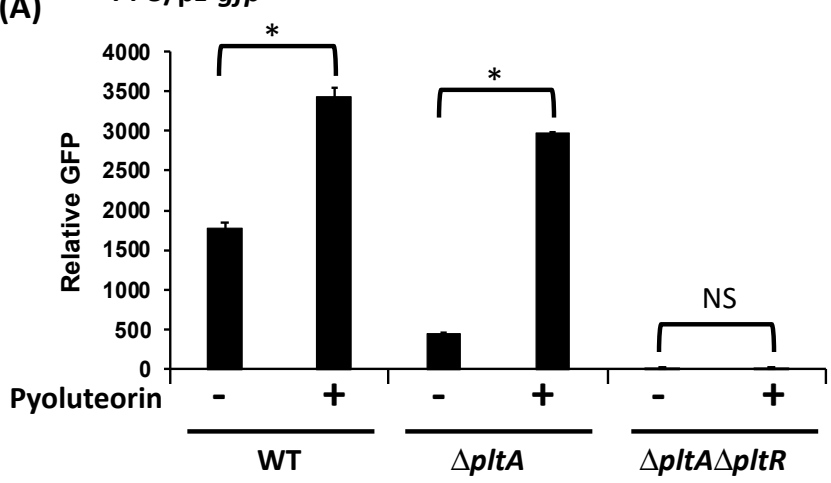

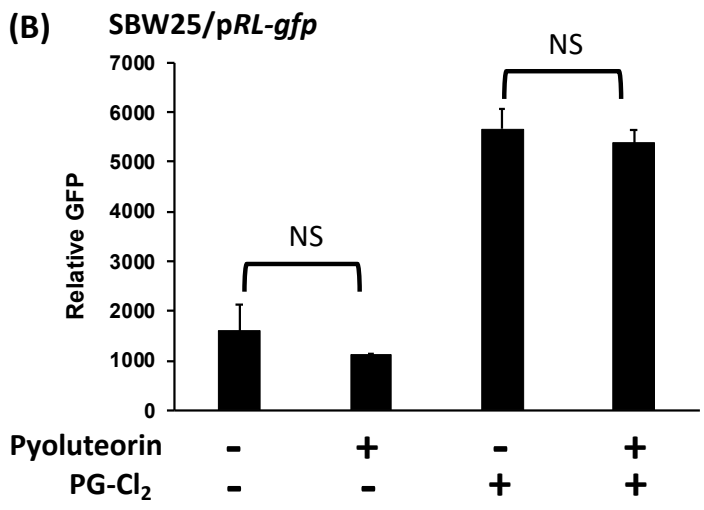

Figure 2. Autoinduction of pyoluteorin biosynthesis genes requires $p l t R$. (A) pltL promoter activity was measured using the GFP reporter construct $\mathrm{pL}$-gfp in wild type (WT) Pf-5 and its mutants. (B) pltL promoter activity was measured using the GFP reporter construct $p R L-g f p$ in strain SBW25. The promoter activity was measured as relative GFP (fluorescence of GFP divided by $\mathrm{OD}_{600}$ ) recorded at $24 \mathrm{~h}(\mathbf{A})$ and $15 \mathrm{~h}(\mathbf{B})$ post inoculation (hpi). Pyoluteorin and PG-Cl $\mathrm{C}_{2}$ were added to the cultures at a concentration of $1 \mu \mathrm{M}$ and $10 \mathrm{nM}$, respectively. The inducing effect of $\mathrm{PG}-\mathrm{Cl}_{2}$ on pltL promoter activity has been reported previously [24] and is confirmed in this study. ${ }^{*}$ indicates treatments are significantly different $(p<0.05)$, as determined by the Student $t$-test. NS: not significant. Data are means and standard deviations of at least three biological replicates from a representative experiment repeated three times with similar results.

pltR encodes a transcriptional regulator known to activate the expression of pyoluteorin biosynthesis genes in Pf-5 (Figure 1) [21]. Consistent with the previous report, 
mutation of $p l t R$ in the $\triangle p l t A$ mutant background markedly reduced $p l t L$ promoter activity (Figure 2A). Adding pyoluteorin into the $\Delta p l t A \Delta p l t R$ mutant did not induce $p l t L$ promoter activity, indicating $p l t R$ is indispensable in pyoluteorin autoinduction (Figure $2 \mathrm{~A}$ ).

To test if $p l t R$ is sufficient for the autoinduction, we measured $p l t L$ promoter activity in $P$. fluorescens SBW25 using a reporter construct $p R L-g f p$, which contains the pltR gene and the pltL promoter fused with a promoterless $g f p$ (Figure 1C) [24]. Strain P. fluorescens SBW25 does not contain pyoluteorin biosynthesis genes [34] but, if pltR is introduced, strain SBW25 has the genetic capability to activate $p l t L$ transcription as proven by induced pltL promoter activity with $\mathrm{PG}-\mathrm{Cl}_{2}$ treatment (Figure $2 \mathrm{~B}$ ). Results show that pyoluteorin could not induce pltL promoter activity in SBW25/pRL-gfp (Figure 2B), indicating that $p l t R$ is not sufficient for pyoluteorin autoinduction. To test the possibility that PltR is sufficient for autoinduction in the presence of both pyoluteorin and $\mathrm{PG}-\mathrm{Cl}_{2}$, both compounds were added to the cultures of SBW25/pRL-gfp. Results show that pyoluteorin did not enhance plt L expression in the presence of $\mathrm{PG}-\mathrm{Cl}_{2}$ (Figure $2 \mathrm{~B}$ ).

Collectively, these results indicate that PltR is indispensable for the transcription of pyoluteorin biosynthesis genes, but an additional regulatory factor(s) is(are) needed for autoinduction of pyoluteorin.

\subsection{PltZ Is an Autorepressor and Directly Represses Expression of Linked Transporter Genes}

In addition to $p l t R$, the $p l t$ gene cluster encodes another transcriptional regulator PltZ (Figure 1B). Homologs of pltZ genes repress the expression of linked transporter genes in $P$. aeruginosa strains M18 [35] and ATCC 27853 [36]. The substrate of the encoded transporter (termed PltIJKNOP in P. protegens Pf-5) has not been demonstrated, and the function of PltZ in $P$. protegens has not been characterized. In this work, plt $Z$ was deleted in the $\Delta p l t A$ mutant of Pf-5, which generated a $\Delta p l t A \Delta p l t Z$ double mutant. Two reporter constructs, $\mathrm{pZ}-g f p$ and $\mathrm{p} I-g f p$, containing the promoter of $p l t Z$ and $p l t I$ respectively fused with a promoterless $g f p$, were made to test if $\mathrm{Plt} Z$ regulates the expression of itself or the linked transporter genes pltIJKNOP (Figure 1). Relative to $\triangle$ pltA mutant, $\Delta$ pltA $\Delta$ pltZ mutant showed a significantly higher pltZ promoter activity (Figure $3 \mathrm{~A}$ ), indicating that PltZ negatively regulates its own transcription. We further tested pltZ promoter activity in strain P. fluorescens SBW25 carrying a functional pltZ on the expression plasmid pME6010-pltZ. Results show that $p l t Z$ markedly decreased its own transcription in SBW25 (Figure 3B), suggesting that PltZ is an autorepressor that directly regulates the transcription of itself.

(A)

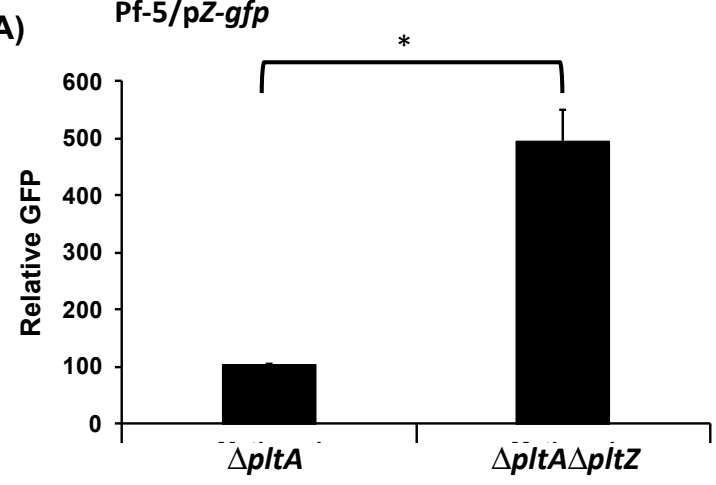

(B)

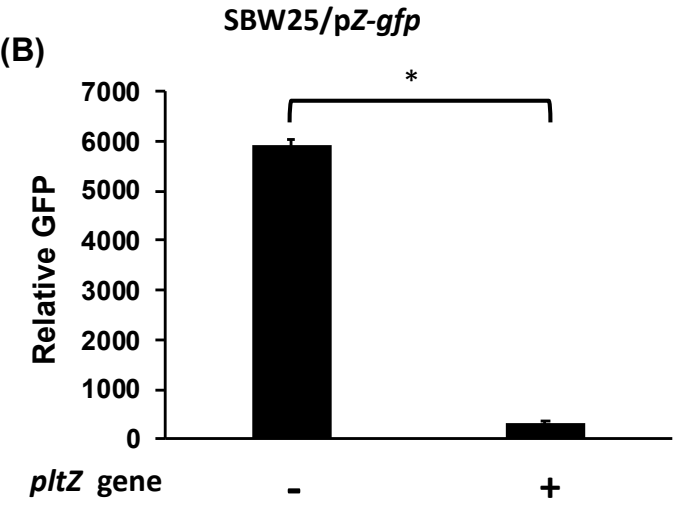

Figure 3. Autorepression of $p l t Z$. Promoter activity of $p l t Z$ was measured using the GFP reporter construct pZ-gfp in Pf-5 mutants (A), or in strain SBW25 with or without the presence of the expression construct pME6010-pltZ (B). Promoter activity was measured as relative GFP recorded at $24 \mathrm{hpi} .{ }^{*}$ indicates treatments are significantly different $(p<0.05)$, as determined by the Student's t-test. Data are means and standard deviations of at least three biological replicates from a representative experiment repeated three times with similar results.

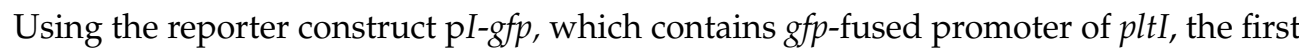
gene of the pltIJKNOP transcriptional unit [37], we show that pltI promoter activity was 
significantly higher in the $\Delta p l t A \Delta p l t Z$ mutant than in the $\Delta p l t A$ mutant (Figure $4 \mathrm{~A}$ ). These results indicate that PltZ represses the transcription of pltIJKNOP transporter genes in Pf-5. Further, pltZ significantly reduced pltI promoter activity in strain SBW25 (Figure 4B), indicating that PltZ directly represses transcription of pltIJKNOP transporter genes.

(A)

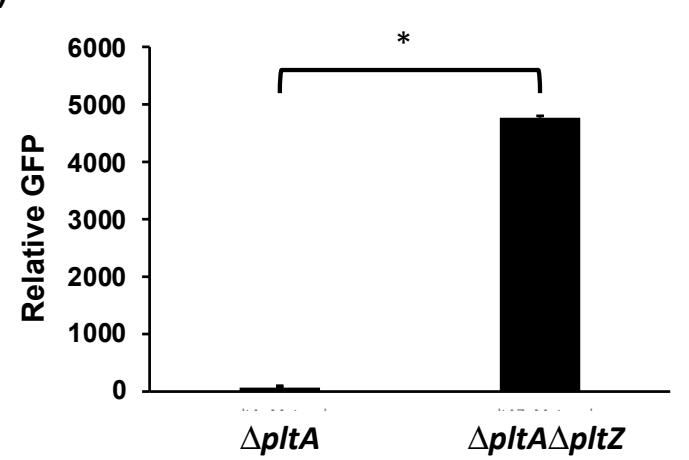

(B)

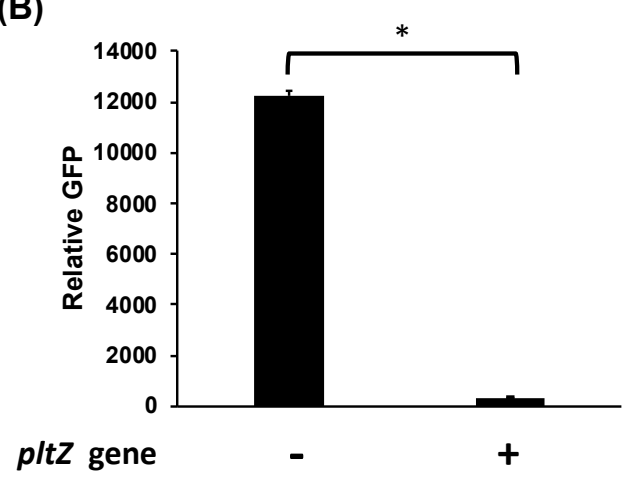

Figure 4. Repression of pltI promoter activity by pltZ. Promoter activity of pltI was measured using the GFP reporter construct $\mathrm{pI-gfp}$ in Pf-5 mutants (A), or in strain SBW25 with or without the presence of expression construct pME6010-pltZ (B). Promoter activity was measured as relative GFP recorded at $24 \mathrm{hpi}$. * indicates treatments are significantly different $(p<0.05)$, as determined by the Student's $t$-test. Data are means and standard deviations of at least three biological replicates from a representative experiment repeated three times with similar results.

We then purified PltZ protein and tested if PltZ binds to the pltI promoter in vitro. Results of gel shifting assays show a clear shift of the labeled pltIZ DNA probe which contains pltI promoter (Figure 5A,B), but not the pltRL DNA probe that contains pltL promoter (Figure 5C,D), in the presence of PltZ protein, thus confirming the direct regulation of the pltIJKNOP transcriptional unit by PltZ. The PltZ-pltIZ $Z_{\text {probe }}$ protein-DNA complex can be disintegrated by pyoluteorin at micromolar concentrations, that are within the physiological range of Pf-5 [24], as revealed by the released free DNA probe in the presence of pyoluteorin. This result shows that pyoluteorin reduces the binding affinity of PltZ to the promoter region of the pltIJKNOP transcriptional unit.

Collectively, our results show that PltZ is an autorepressor and directly represses the transcription of pltIJKNOP transporter genes in strain Pf-5.

\subsection{Pyoluteorin Interacts with PltZ and Relieves PltZ-Mediated Transcriptional Repression of pltIJKNOP Transporter Genes}

PltZ belongs to the TetR family of regulators that usually interact with small molecules or protein ligands, which then change their regulatory activities [38]. We have shown that pyoluteorin can release the DNA probe that contains the pltI promoter region from the PltZ-pltIZ $Z_{\text {probe }}$ complex (Figure 5AB). To test if pyoluteorin serves as an inducer to relieve PltZ-mediated repression of the pltIJKNOP transcriptional unit, pyoluteorin was added into cultures of strain SBW25 containing the reporter construct pI-gfp and the expression plasmid pME6010-pltZ. Our result show that pyoluteorin significantly increased pltI promoter activity (Figure 6A), suggesting that pyoluteorin is likely an inducer of PltZ.

We then tested the interaction of pyoluteorin and PltZ using two independent approaches. In the first spectrophotometer assay, adding pyoluteorin to a PltZ protein solution resulted in a new absorbance peak at around $375 \mathrm{~nm}$ (Figure 6B), likely caused by the PltZ-pyoluteorin complex. Continued addition of pyoluteorin generated a second new absorbance peak at around $315 \mathrm{~nm}$, which is identical to the free pyoluteorin compound. Elution of the protein-compound solution through G25 column maintained the absorbance peak at around $375 \mathrm{~nm}$, but markedly reduced absorbance at around $315 \mathrm{~nm}$ (Figure 6B, inner figure), likely due to the removed free pyoluteorin compound that was retained on the column. The binding of pyoluteorin to PltZ was further evaluated in an isothermal 
titration calorimetry (ITC) assay. Adding pyoluteorin compound into PltZ protein solution markedly changed the protein conformation of PltZ at a molar ratio around 0.5 (Figure 6C). Data fitting revealed that pyoluteorin binds to PltZ with a binding affinity of around $13.2 \mathrm{nM}$.

(A)

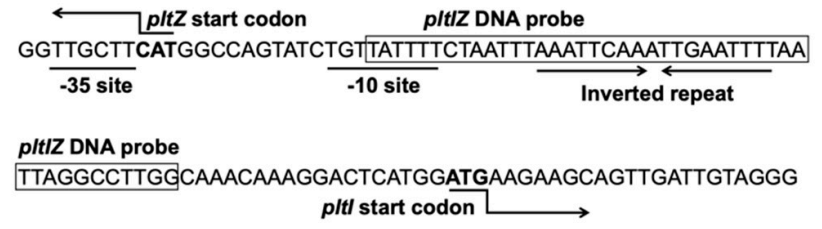

(B)

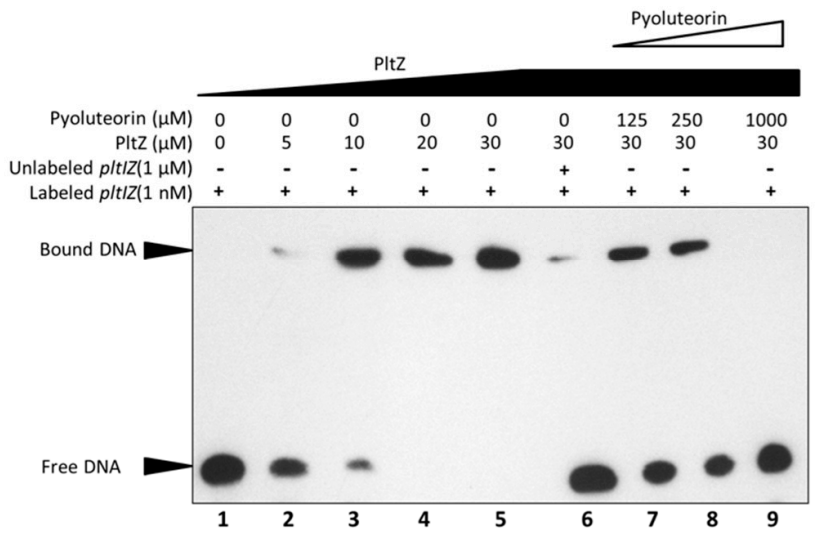

(C)

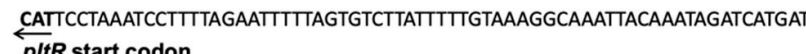
pltR start codon

(.... 262 nucleotides" between p/tR and $p / t L$....)

pltRL DNA probe CGTTAAGTTGTGTTGGCTTCGATGTTG TCGGGGCTGTTTTGCCTTGGGGATATGCAAAGGCCTT

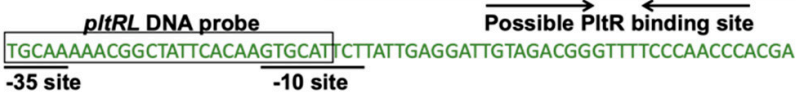
TTGTCGAATGCAGGAGCGTACGTCTATGGACGGAGAG pltL start codon

(D)

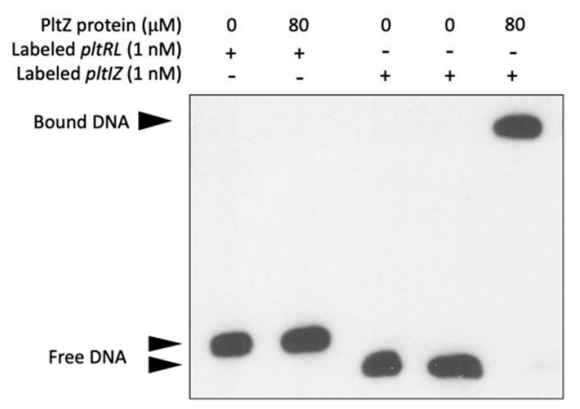

Figure 5. PltZ binds to the pltI-pltZ intergenic region. (A) Intergenic region between pltI and pltZ in the chromosome of Pf-5. The predicted -10 and -35 sites of pltI promoter and an inverted repeat are shown. (B) EMSA binding assay of interactions between PltZ protein, the pltIZ DNA probe (shown in (A)), and the pyoluteorin compound. The interactions were performed in $20 \mu \mathrm{L}$ reactions at $25^{\circ} \mathrm{C}$. Lane 1 serves as a control which contains only labeled pltIZ DNA probe; lanes 2 to 5 contain labeled pltIZ probe and different concentrations of PltZ protein; lane 6 contains unlabeled pltIZ DNA fragment to compete for PltZ protein; lanes 7 to 9 contain different concentrations of pyoluteorin to test if this compound releases the pltIZ probe from its binding complex with PltZ. (C) Intergenic region between pltR and pltL in the chromosome of Pf-5. The predicted -10 and -35 sites of pltL promoter and a possible PltR binding site similar to the lys box identified in P. aeruginosa M18 [22] are shown. *: 262 nucleotides between the indicated pltR and pltL intergenic region are not shown. The DNA fragment labeled with green color was fused with a promoterless $g f p$ to monitor the promoter activity of $p l t L$ in the reporter construct $\mathrm{pL-gfp}$ that was made previously [32] and used in this study (Figure 1C). (D) EMSA binding assay of interactions between PltZ protein and the pltRL DNA probe (shown in (C)). The pltIZ DNA probe used in (B) served as a positive control. The experiments were repeated at least two times.

Together, these results demonstrate that pyoluteorin binds PltZ as an inducer, relieving the PltZ-mediated transcriptional repression of pltIJKNOP transporter genes.

\subsection{PltZ Is Involved in the Autoinduction of Pyoluteorin}

Based on our results that pyoluteorin interacts with PltZ to derepress transporter genes in the pyoluteorin gene cluster, in addition to the known coordinate regulation of the biosynthesis and transport genes [37], we hypothesized that PltZ is involved in the autoinduction of pyoluteorin. To test this hypothesis, the $\mathrm{p} L-g f p$ reporter construct was moved into the $\Delta$ pltA $\Delta$ pltZ mutant, and pltL promoter activity of the resultant reporter strain was measured with or without pyoluteorin treatment. Mutation of $p l t Z$ markedly increased the promoter activity of pltL (Figure 7), which is consistent with the previous report that pltZ negatively regulates pyoluteorin production of P. aeruginosa M18 [39]. Importantly, plt $L$ promoter activity could not be further induced by pyoluteorin amendment in the $\Delta p l t A \Delta p l t Z$ mutant, indicating that PltZ is necessary for pyoluteorin autoinduction. 
(A)

(B)

SBW25/pl-gfp + pME6010-pltZ

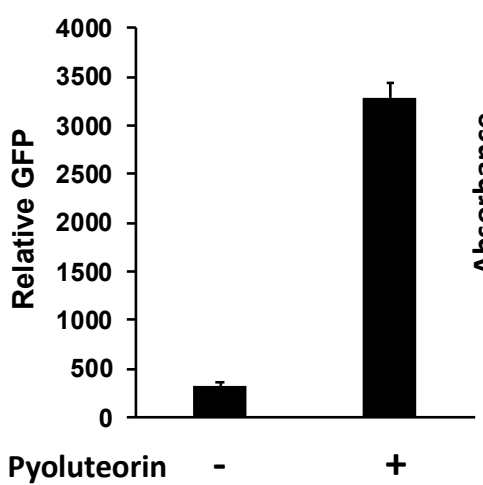

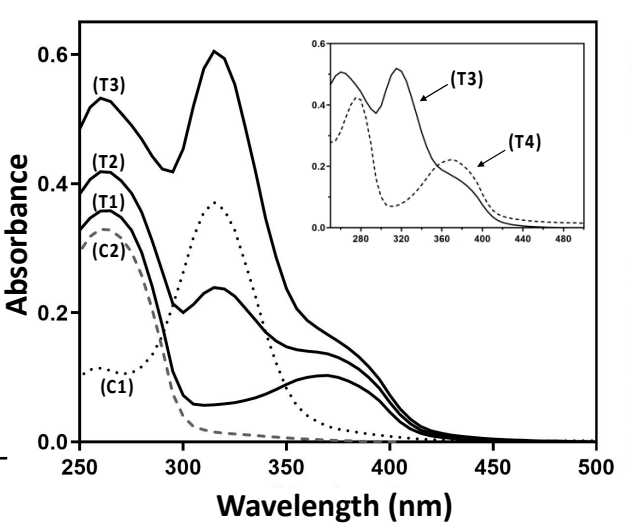

(C) Time (min)

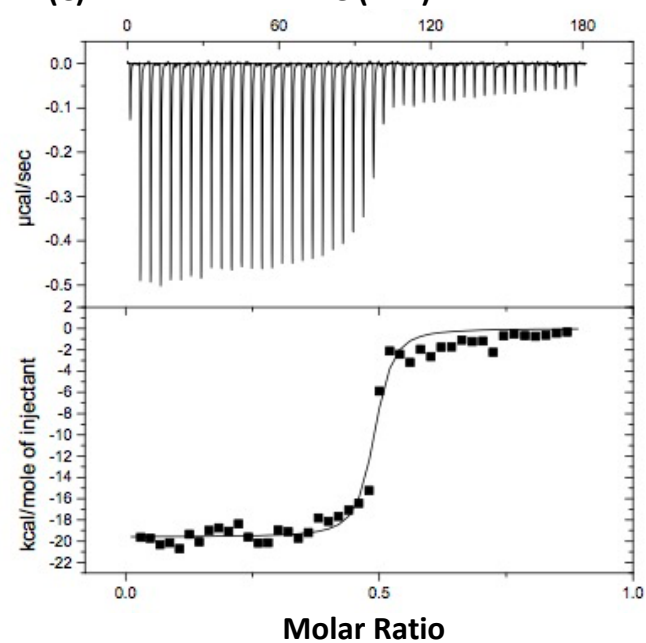

Figure 6. Pyoluteorin relieves PltZ-mediated repression on pltI promoter activity (A) and binds to PltZ protein in vitro $(B, C)$. (A) Promoter activity of pltI was measured in strain SBW25 containing the GFP reporter construct pI-gfp and the expression construct pME6010-pltZ with or without the addition of pyoluteorin $(1 \mu \mathrm{M})$. The promoter activity was measured as relative GFP recorded at $24 \mathrm{hpi}$. Data are means and standard deviations of at least three biological replicates from a representative experiment repeated three times with similar results. (B) Pyoluteorin was added into PltZ protein solution in Tris- $\mathrm{HCl}$ buffer at different concentrations. The absorbance profile of the mixtures was monitored. C1: control protein solution that has free purified PltZ protein. C2: control compound solution that has free purified pyoluteorin compound. T1 to T3: mixtures of PltZ protein $(39 \mu \mathrm{M})$ and pyoluteorin compound at $7.5 \mu \mathrm{M}$ (T1), $32 \mu \mathrm{M}$ (T2), $57.5 \mu \mathrm{M}$ (T3). T4 (inner figure): filtrates of T3 eluted from a Sephadex G-25 column. (C) Binding isotherm for the pyoluteorin-PltZ interaction. The integrated heat was plotted against the molar ratio between the ligand and the protein. Data fitting revealed a binding affinity of about $13.2 \mathrm{nM}$. The experiments of $(\mathbf{B}, \mathbf{C})$ were repeated two times.

Pf-5/pL-gfp

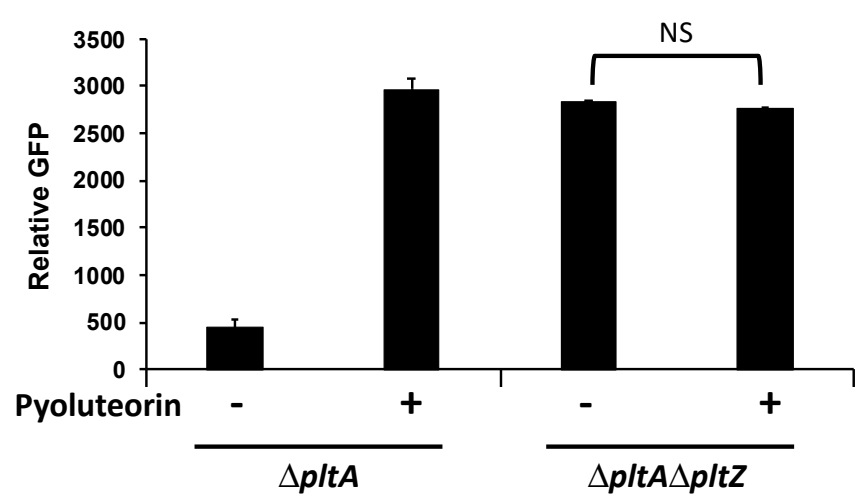

Figure 7. Autoinduction of pyoluteorin biosynthesis genes requires pltZ. pltL promoter activity was measured using the GFP reporter construct $\mathrm{p} L-g f p$ in Pf-5 mutants. The promoter activity was measured as relative GFP recorded at $24 \mathrm{hpi}$. Pyoluteorin was added to the cultures at a concentration of $1 \mu \mathrm{M}$. NS: not significant $(p>0.05)$, as determined by the Student's $t$-test. Data are means and standard deviations of at least three biological replicates from a representative experiment repeated three times with similar results.

\section{Discussion}

Understanding the regulation of antibiotic production is of great interest not only in basic microbiology but also in clinical, industrial, and agricultural microbiology. Autoinduction is a widespread regulatory mechanism of antibiotic production, allowing producing microorganisms to quickly accumulate antibiotics in response to changing environmental conditions [7]. Here, using P. protegens Pf-5 as a model, we report an alternative 
mechanism of autoinduction by which two pathway-specific transcriptional regulators PltR and PltZ are both required for the autoinduction of the antibiotic pyoluteorin.

Both PltR and PltZ are required for pyoluteorin autoinduction but they play different regulatory roles. The requirement of PltR is consistent with previous reports that PltR protein directly binds to $p l t L$ promoter and activates transcription of pyoluteorin biosynthesis genes in P. aeruginosa M18 [22], and that mutation of pltR abolishes pyoluteorin production in P. protegens Pf-5 [21]. Together, these data show that PltR plays an indispensable role in pyoluteorin autoinduction because it is required for expression of pyoluteorin biosynthesis genes. Although PltZ is also required for pyoluteorin autoinduction, it is not necessary for the basal levels of expression of pyoluteorin biosynthesis genes or pyoluteorin production. Instead, mutation of $p l t Z$ enhanced $p l t L$ transcription in Pf-5 (Figure 7). Similarly, mutation of pltZ increased pyoluteorin yield and transcription of pyoluteorin biosynthesis genes in M18 [39]. These results suggest that the pathway-specific regulation of pyoluteorin biosynthesis gene expression involves at least two processes: a basal level of regulation (transcriptional activation) mediated by PltR and a higher level of regulation (autoinduction) mediated by PltZ. This mechanism differs from the known mechanisms of antibiotic autoinduction, which involves a single pathway-specific transcriptional regulator that perceives an antibiotic (or a biosynthetic intermediates) as a signal and directly stimulates transcription of the antibiotic biosynthesis genes [14,16].

The mechanisms by which PltZ mediates pyoluteorin autoinduction were not investigated in this study. However, we proved that pyoluteorin alters PltZ-mediated direct regulation of pltIJKNOP transcription with the following evidences: (1) pltZ repressed pltI promoter activity heterogeneously in strain SBW25 (Figure 4B); (2) pyoluteorin relieved PltZ-mediated repression of pltI promoter activity in SBW25 (Figure 6A); (3) PltZ bound

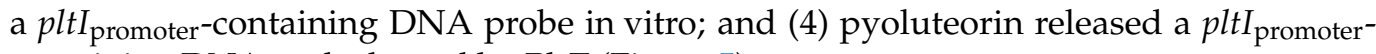
containing DNA probe bound by PltZ (Figure 5).

The direct interaction between pyoluteorin and PltZ and the direct regulation of pltIJKNOP transporter gene expression by PltZ, together with the result that mutation of pltZ abolished autoinduction of pyoluteorin (Figure 7), prompt us to hypothesize that the PltIJKNOP transporter is involved in pyoluteorin autoinduction. Although the substrate(s) of this transporter remain(s) unidentified, it is known to be required for a normal production level of pyoluteorin: mutation of the transporter encoding genes decreased pyoluteorin yield in strains Pf-5 and M18 [37,40]. Bioinformatic analysis indicates that the PltIJKNOP transporter system likely serves as an exporter in pumping out intracellular metabolites $[37,40]$. One possible mechanism of pyoluteorin autoinduction is that the PltIJKNOP transporter, activated by pyoluteorin, exports and reduces intracellular level of metabolite(s) that is(are) repressive to transcription of pyoluteorin biosynthesis genes. Repressive metabolite(s) can be generated before pyoluteorin biosynthesis. For example, phloroglucinol (PG), the precursor of $\mathrm{PG}^{-\mathrm{Cl}_{2}}$ [24], is known to inhibit transcription of pyoluteorin biosynthesis genes at micromolar concentrations via an uncharacterized mechanism [41]. Repressive metabolite(s) may also be generated during pyoluteorin biosynthesis. Intermediates of many antibiotic biosynthesis pathways have been found to function as signaling molecules in self-protection and/or production of resultant metabolites [42-44]. Future efforts are needed to investigate if the PltIJKNOP transporter is involved in the PltZ-mediated autoinduction of pyoluteorin, and if PG and/or other potential repressive metabolites of pyoluteorin biosynthesis can be exported by the PltIJKNOP transporter and their roles in the autoinduction of pyoluteorin.

Another possible mechanism by which PltZ controls pyoluteorin autoinduction is that PltZ may directly bind to $p l t L$ promoter and repress the expression of pyoluteorin biosynthesis genes. Pyoluteorin may relieve this repression, resulting in an enhanced transcription of pyoluteorin biosynthesis genes and antibiotics production. A 16-bp semipalindromic PltZ-binding DNA motif (TNNAATTNNAATTNNA) identified in P. aeruginosa ATCC 27853 [36] is also present in the pltI promoter region of Pf-5 (Figure 5A). However, this PltZ-binding DNA motif was not found in the pltL promoter region (Figure 5C), and 
no interaction was observed between PltZ and a DNA fragment containing the intergenic region between $p l t R$ and pltL of Pf-5 (Figure 5D) or P. aeruginosa ATCC 27853 [36], suggesting that PltZ is unlikely to regulate $p l t L$ directly.

In summary, we report that pyoluteorin serves as an inducer that binds to PltZ and relieves PltZ-mediated repression of pltIJKNOP transcription. Results of this study also show that $p l t Z$, together with the other pathway-specific transcriptional regulator $p l t R$, is essential for autoinduction of pyoluteorin in Pf-5.

Author Contributions: Conceptualization, Q.Y. and J.E.L.; Investigation, Q.Y., M.L., T.K., and C.P.J., Writing—original draft preparation, Q.Y.; Writing—review and editing, Q.Y., M.L., T.K., C.P.J., and J.E.L.; Supervision, J.E.L. and Q.Y.; Project administration, J.E.L.; Funding acquisition, J.E.L. and Q.Y. All authors have read and agreed to the published version of the manuscript.

Funding: This project was supported by National Research Initiative Competitive Grant 2011-6701930192 from the USDA National Institute of Food and Agriculture, and Startup funds from the Department of Plant Sciences and Plant Pathology at Montana State University.

Institutional Review Board Statement: Not applicable.

Informed Consent Statement: Not applicable.

Acknowledgments: We are grateful to Nathan Jespersen, Elisar Barbar, Brenda Shaffer, and Virginia Stockwell for their assistance. We are grateful to Jeff Chang and Jeff Anderson for their helpful discussions.

Conflicts of Interest: The authors declare no conflict of interest.

\section{References}

1. Kjelleberg, S.; Molin, S. Is There a Role for Quorum Sensing Signals in Bacterial Biofilms? Curr. Opin. Microbiol. 2002, 5, 254-258. [CrossRef]

2. Smits, W.K.; Kuipers, O.P.; Veening, J.-W. Phenotypic Variation in Bacteria: The Role of Feedback Regulation. Nat. Rev. Microbiol. 2006, 4, 259-271. [CrossRef] [PubMed]

3. Groisman, E.A. Feedback Control of Two-Component Regulatory Systems. Annu. Rev. Microbiol. 2016, 70, 103-124. [CrossRef] [PubMed]

4. Camilli, A.; Bassler, B.L. Bacterial Small-Molecule Signaling Pathways. Science 2006, 311, 1113-1116. [CrossRef]

5. Kuipers, O.P.; Beerthuyzen, M.M.; De Ruyter, P.G.; Luesink, E.J.; De Vos, W.M. Autoregulation of Nisin Biosynthesis in Lactococcus lactis by Signal Transduction. J. Biol. Chem. 1995, 270, 27299-27304. [CrossRef]

6. Fish, S.A.; Cundliffe, E. Stimulation of Polyketide Metabolism in Streptomyces fradiae by Tylosin and Its Glycosylated Precursors. Microbiology 1997, 143, 3871-3876. [CrossRef]

7. Schnider-Keel, U.; Seematter, A.; Maurhofer, M.; Blumer, C.; Duffy, B.; Gigot-Bonnefoy, C.; Reimmann, C.; Notz, R.; Défago, G.; Haas, D.; et al. Autoinduction of 2,4-Diacetylphloroglucinol Biosynthesis in the Biocontrol Agent Pseudomonas fluorescens CHA0 and Repression by the Bacterial Metabolites Salicylate and Pyoluteorin. J. Bacteriol. 2000, 182, 1215-1225. [CrossRef]

8. Stein, T.; Borchert, S.; Kiesau, P.; Heinzmann, S.; Klöss, S.; Klein, C.; Helfrich, M.; Entian, K.-D. Dual Control of Subtilin Biosynthesis and Immunity in Bacillus subtilis. Mol. Microbiol. 2002, 44, 403-416. [CrossRef]

9. Brodhagen, M.; Henkels, M.D.; Loper, J.E. Positive Autoregulation and Signaling Properties of Pyoluteorin, an Antibiotic Produced by the Biological Control Organism Pseudomonas fluorescens Pf-5. Appl. Environ. Microbiol. 2004, 70, 1758-1766. [CrossRef]

10. Inaoka, T.; Takahashi, K.; Yada, H.; Yoshida, M.; Ochi, K. RNA Polymerase Mutation Activates the Production of a Dormant Antibiotic 3, 3'-Neotrehalosadiamine via an Autoinduction Mechanism in Bacillus subtilis. J. Biol. Chem. 2004, $279,3885-3892$. [CrossRef]

11. Kim, J.; Kim, J.-G.; Kang, Y.; Jang, J.Y.; Jog, G.J.; Lim, J.Y.; Kim, S.; Suga, H.; Nagamatsu, T.; Hwang, I. Quorum Sensing and the LysR-Type Transcriptional Activator ToxR Regulate Toxoflavin Biosynthesis and Transport in Burkholderia glumae. Mol. Microbiol. 2004, 54, 921-934. [CrossRef] [PubMed]

12. Jiang, H.; Hutchinson, C.R. Feedback Regulation of Doxorubicin Biosynthesis in Streptomyces peucetius. Res. Microbiol. 2006, 157, 666-674. [CrossRef] [PubMed]

13. Schmitz, S.; Hoffmann, A.; Szekat, C.; Rudd, B.; Bierbaum, G. The Lantibiotic Mersacidin Is an Autoinducing Peptide. Appl. Environ. Microbiol. 2006, 72, 7270-7277. [CrossRef] [PubMed]

14. Wang, L.; Tian, X.; Wang, J.; Yang, H.; Fan, K.; Xu, G.; Yang, K.; Tan, H. Autoregulation of Antibiotic Biosynthesis by Binding of the End Product to an Atypical Response Regulator. Proc. Natl. Acad. Sci. USA 2009, 106, 8617-8622. [CrossRef]

15. Sherwood, E.J.; Bibb, M.J. The Antibiotic Planosporicin Coordinates Its Own Production in the Actinomycete planomonospora Alba. Proc. Natl. Acad. Sci. USA 2013, 110, E2500-E2509. [CrossRef] 
16. Abbas, A.; Morrissey, J.P.; Marquez, P.C.; Sheehan, M.M.; Delany, I.R.; O'Gara, F. Characterization of Interactions between the Transcriptional Repressor PhlF and Its Binding Site at the phlA Promoter in Pseudomonas fluorescens F113. J. Bacteriol. 2002, 184, 3008-3016. [CrossRef]

17. Takeda, R. Pseudomonas Pigments. I. Pyoluteorin, a New Chlorine-Containing Pigment Produced by Pseudomonas aeruginosa. Hako Kogaku Zasshi 1958, 31, 281-290.

18. Howell, C.R.; Stipanovic, R.D. Suppression of Pythium Ultimum-Induced Damping-off of Cotton Seedlings by Pseudomonas fluorescens and Its Antibiotic, Pyoluteorin. Phytopathology 1980, 70, 712-715. [CrossRef]

19. Baehler, E.; Bottiglieri, M.; Péchy-Tarr, M.; Maurhofer, M.; Keel, C. Use of Green Fluorescent Protein-Based Reporters to Monitor Balanced Production of Antifungal Compounds in the Biocontrol Agent Pseudomonas fluorescens CHA0. J. Appl. Microbiol. 2005, 99, 24-38. [CrossRef]

20. Ge, Y.H.; Zhao, Y.H.; Chen, L.J.; Miao, J.; Wen, L. Autoinduction of Pyoluteorin and Correlation between Phenazine-1-Carboxylic Acid and Pyoluteorin in Pseudomonas sp. M18. Wei Sheng Wu Xue Bao Acta Microbiol. Sin. 2007, 47, 441-446.

21. Nowak-Thompson, B.; Chaney, N.; Wing, J.S.; Gould, S.J.; Loper, J.E. Characterization of the Pyoluteorin Biosynthetic Gene Cluster of Pseudomonas fluorescens Pf-5. J. Bacteriol. 1999, 181, 2166-2174. [CrossRef] [PubMed]

22. Li, S.; Huang, X.; Wang, G.; Xu, Y. Transcriptional Activation of Pyoluteorin Operon Mediated by the LysR-Type Regulator PltR Bound at a 22 Bp lys Box in Pseudomonas aeruginosa M18. PLoS ONE 2012, 7, e39538. [CrossRef]

23. Maddocks, S.E.; Oyston, P.C. Structure and Function of the LysR-Type Transcriptional Regulator (LTTR) Family Proteins. Microbiology 2008, 154, 3609-3623. [CrossRef]

24. Yan, Q.; Philmus, B.; Chang, J.H.; Loper, J.E. Novel Mechanism of Metabolic Co-Regulation Coordinates the Biosynthesis of Secondary Metabolites in Pseudomonas protegens. eLife 2017, 6, e22835. [CrossRef]

25. King, E.O.; Ward, M.K.; Raney, D.E. Two Simple Media for the Demonstration of Pyocyanin and Fluorescin. J. Lab. Clin. Med. 1954, 44, 301-307.

26. Howell, C.R.; Stipanovic, R.D. Control of Rhizoctonia Solani in Cotton Seedlings with Pseudomonas fluorescens and with an Antibiotic Produced by the Bacterium. Phytopathology 1979, 69, 480-482. [CrossRef]

27. Henkels, M.D.; Kidarsa, T.A.; Shaffer, B.T.; Goebel, N.C.; Burlinson, P.; Mavrodi, D.V.; Bentley, M.A.; Rangel, L.I.; Davis, E.W.; Thomashow, L.S.; et al. Pseudomonas protegens Pf-5 Causes Discoloration and Pitting of Mushroom Caps Due to the Production of Antifungal Metabolites. Mol. Plant-Microbe Interact. 2014, 27, 733-746. [CrossRef]

28. Silby, M.W.; Cerdeño-Tárraga, A.M.; Vernikos, G.S.; Giddens, S.R.; Jackson, R.W.; Preston, G.M.; Zhang, X.-X.; Moon, C.D.; Gehrig, S.M.; Godfrey, S.A. Genomic and Genetic Analyses of Diversity and Plant Interactions of Pseudomonas fluorescens Genome Biol. 2009, 10, 1-16. [CrossRef]

29. Simon, R.; Priefer, U.; Pühler, A. A Broad Host Range Mobilization System for in vivo Genetic Engineering: Transposon Mutagenesis in Gram Negative Bacteria. Nat. Biotechnol. 1983, 1, 784-791. [CrossRef]

30. Hoang, T.T.; Karkhoff-Schweizer, R.R.; Kutchma, A.J.; Schweizer, H.P. A Broad-Host-Range Flp-FRT Recombination System for Site-Specific Excision of Chromosomally-Located DNA Sequences: Application for Isolation of Unmarked Pseudomonas aeruginosa Mutants. Gene 1998, 212, 77-86. [CrossRef]

31. Miller, W.G.; Leveau, J.H.; Lindow, S.E. Improved $g f p$ and inaZ Broad-Host-Range Promoter-Probe Vectors. Mol. Plant-Microbe Interact. 2000, 13, 1243-1250. [CrossRef]

32. Yan, Q.; Philmus, B.; Hesse, C.; Kohen, M.; Chang, J.H.; Loper, J. The Rare Codon AGA Is Involved in Regulation of Pyoluteorin Biosynthesis in Pseudomonas protegens Pf-5. Front. Microbiol. 2016, 7, 497. [CrossRef]

33. Heeb, S.; Itoh, Y.; Nishijyo, T.; Schnider, U.; Keel, C.; Wade, J.; Walsh, U.; O'Gara, F.; Haas, D. Small, Stable Shuttle Vectors Based on the Minimal PVS1 Replicon for Use in Gram-Negative, Plant-Associated Bacteria. Mol. Plant-Microbe Interact. 2000, 13, $232-237$. [CrossRef]

34. Loper, J.E.; Hassan, K.A.; Mavrodi, D.V.; Davis, E.W., II; Lim, C.K.; Shaffer, B.T.; Elbourne, L.D.; Stockwell, V.O.; Hartney, S.L.; Breakwell, K. Comparative Genomics of Plant-Associated Pseudomonas spp.: Insights into Diversity and Inheritance of Traits Involved in Multitrophic Interactions. PLoS Genet. 2012, 8, e1002784. [CrossRef]

35. Huang, X.-Q.; Ge, Y.-H.; Zhang, X.-H.; Xu, Y.Q. Transcriptional Repression of PltZ on Pyoluteorin ABC Transporter of Pseudomonas sp. M18. Wei Sheng Wu Xue Bao Acta Microbiol. Sin. 2005, 45, 344-348.

36. Guo, D.-D.; Luo, L.-M.; Ma, H.-L.; Zhang, S.-P.; Xu, H.; Zhang, H.; Wang, Y.; Yuan, Y.; Wang, Z.; He, Y.-X. The Regulator PltZ Regulates a Putative ABC Transporter System PltIJKNOP of Pseudomonas aeruginosa ATCC 27853 in Response to the Antimicrobial 2, 4-Diacetylphloroglucinol. Front. Microbiol. 2020, 11, 1423. [CrossRef] [PubMed]

37. Brodhagen, M.; Paulsen, I.; Loper, J.E. Reciprocal Regulation of Pyoluteorin Production with Membrane Transporter Gene Expression in Pseudomonas fluorescens Pf-5. Appl. Environ. Microbiol. 2005, 71, 6900-6909. [CrossRef] [PubMed]

38. Cuthbertson, L.; Nodwell, J.R. The TetR Family of Regulators. Microbiol. Mol. Biol. Rev. 2013, 77, 440-475. [CrossRef]

39. Huang, X.; Zhu, D.; Ge, Y.; Hu, H.; Zhang, X.; Xu, Y. Identification and Characterization of pltZ, a Gene Involved in the Repression of Pyoluteorin Biosynthesis in Pseudomonas sp. M18. FEMS Microbiol. Lett. 2004, 232, 197-202. [CrossRef]

40. Huang, X.; Yan, A.; Zhang, X.; Xu, Y. Identification and Characterization of a Putative ABC Transporter PltHIJKN Required for Pyoluteorin Production in Pseudomonas sp. M18. Gene 2006, 376, 68-78. [CrossRef]

41. Kidarsa, T.A.; Goebel, N.C.; Zabriskie, T.M.; Loper, J.E. Phloroglucinol Mediates Crosstalk between the Pyoluteorin and 2,4Diacetylphloroglucinol Biosynthetic Pathways in Pseudomonas fluorescens Pf-5. Mol. Microbiol. 2011, 81, 395-414. [CrossRef] 
42. Xu, Y.; Willems, A.; Au-yeung, C.; Tahlan, K.; Nodwell, J.R. A Two-Step Mechanism for the Activation of Actinorhodin Export and Resistance in Streptomyces coelicolor. MBio 2012, 3, e00191-12. [CrossRef] [PubMed]

43. Yan, X.; Yang, R.; Zhao, R.-X.; Han, J.-T.; Jia, W.-J.; Li, D.-Y.; Wang, Y.; Zhang, N.; Wu, Y.; Zhang, L.-Q. Transcriptional Regulator PhlH Modulates 2, 4-Diacetylphloroglucinol Biosynthesis in Response to the Biosynthetic Intermediate and End Product. Appl. Environ. Microbiol. 2017, 83, e01419-17. [CrossRef] [PubMed]

44. Kong, D.; Wang, X.; Nie, J.; Niu, G. Regulation of Antibiotic Production by Signaling Molecules in Streptomyces. Front. Microbiol. 2019, 10, 2927. [CrossRef] [PubMed] 